\title{
Changes in microbial pathogen dynamics during vermicomposting mixture of cow manure-organic solid waste and cow manure- sewage sludge
}

\author{
Hossein Karimi ${ }^{1} \cdot$ Mehdi Mokhtari $^{1} \cdot$ Faezeh Salehi $^{1} \cdot$ Sajed Sojoudi $^{2}$ \\ Aliasghar Ebrahimi ${ }^{1}$
}

Received: 6 December 2015/ Accepted: 28 December 2016/Published online: 25 January 2017

(c) The Author(s) 2017. This article is published with open access at Springerlink.com

\begin{abstract}
Purpose Microbial pathogens can lead to health problems and disease transmission. Present study aimed to evaluate the microbial quality and quantity of vermicompost production and to compare to the current Iranian standards to protect public health and environmental concerns.

Method This is a pilot-scale experimental study conducted in the Public Health laboratory of Shahid Sadoughi University of Medical Sciences. The samples included organic municipal solid waste, cow manure and wastewater treatment plant sludge which are used for vermicompost production. The samples are mixed as cow manure-organic waste and cow manure-sewage sludge in two reactors. Microbial tests such as fecal coliforms (FC) and parasite egg (Ascaris) were carried out during start, processing and curing time with duplication analysis in 56 days. Totally, a number of 128 samples was analyzed. Analyses were conducted according to standard methods. Data analysis was conducted through one-way ANOVA and Duncan tests.

Results The results showed a significant reduction in number of FCs in cow manure-organic waste so that the number of 350,000 MPN/g in the raw sample decreased to $800 \mathrm{MPN} / \mathrm{g}$ within 8-week period, also FC in the case of cow manure-sewage sludge was achieved to 2400 from
\end{abstract}

Aliasghar Ebrahimi

ebrahimi20007@gmail.com; ebrahimi20007@ssu.ac.ir

1 Environmental Science and Technology Research Center, Department of Environmental Health Engineering, Shahid Sadoughi University of Medical Sciences, Yazd, Iran

2 Department of Occupational Health Engineering, Shahid Sadoughi University of Medical Sciences, Yazd, Iran
$6,500,000 \mathrm{MPN} / \mathrm{g}$. In two cocomposting cases, the parasite eggs were completely removed in the second week.

Conclusion The results showed vermicomposting as a feasible method to convert waste into fertilizer humus in agriculture which also enables to achieve Iranian class A compost standard.

Keywords Vermicompost - Cow manure - Sewage sludge $\cdot$ Solid waste $\cdot$ Parasite egg $\cdot$ Fecal coliform

\section{Introduction}

Due to various agricultural, industrial and restaurant activities in different sectors, lots of organic wastes such as animal manure, sewage sludge, food waste and industrial organic waste are produced. These wastes are disposed by scattering on land surfaces, burning or burial which have the potential to increase global water and soil pollution. Approximately, 50-60\% of the buried disposed waste is composed of organic waste material (Edwards et al. 2010). The continuous increase of waste production has led to the innovation of new approaches which are environmental friendly. Also, conversion of waste into useful materials, compost and vermicomposting can be noted among these methods (Mohammadi et al. 2012).

The nurturing of earth worms in organic waste and its processing to produce fertilizer from waste is called vermicomposting. As a result of organic waste by earth worms, vermicompost comes to successfully convert such wastes as wastewater treatment sludge, dairy plant waste, food waste, municipal waste, paper waste and animal waste into fertilizer. Vermicompost is the result of waste decomposition through the interaction of earthworms and microorganisms. Even though microorganisms are mainly 
responsible for decomposition, earth worms increase microbial activity and changes in biological activity by increasing the contact area (Domínguez 2004).

Vermicomposting is not widely used, due to lack of information about reducing human pathogens in this process. Composting process is exploited in the thermophilic phase, but vermicomposting is exploited in the mesophilic phase in which the temperatures should be kept lower than $35{ }^{\circ} \mathrm{C}$ to prevent the worms dying.

According to the standards set by the Environmental Protection Agency (EPA) to reduce pathogen up to a safe level for use, the compost pile should be exposed to the temperatures of $55-70{ }^{\circ} \mathrm{C}$ for $72 \mathrm{~h}$. So the question is arisen that at the temperatures lower than the standard temperature, like vermicomposting, does the pathogen reduce to a safe level? (Edwards et al. 2010). Several reports have shown the reduction of pathogen to a safe level in the vermicomposting process under specific processing conditions. The first reduction of pathogens was reported by USEPA (1999) where pathogens are reduced by passing biological solid waste through the worm intestine.

Furthermore, Eastman et al. (2001) report a significant reduction of FC and salmonella, studying vermicomposting municipal wastewater solids. Also, Contreras-Ramos et al. (2005) show decrease of pathogen in the vermicompost of cow manure. Monroy et al. (2009) report a reduction of 85-98\% for total coliforms in the process of pig manure vermicomposts. Moreover, Liu et al. (2009) report a decrease of Escherichia coli $\mathrm{O}_{157}: \mathrm{H}_{7}$ bacteria in artificial soil vermicomposts. Rodríguez-Canché et al. (2010), find a decrease of pathogen in the process of septic tank sludge vermicompost. Aira et al. (2011) also report a significant reduction in pathogen through the process of cow manure vermicomposting. Hill and Baldwin (2012) show a decrease of coliforms in toilet vermicomposting. Hill et al. (2013) report the effects of vermicomposting on reducing the number of Ascaris eggs. In a study that was conducted in 2015 by María and Gómez-Brandón (2016), entitled "effects of digestate on soil chemical and microbiological properties: a comparative study with compost and vermicompost", the results show that FC and E. Coli cannot be identified in 60 days.

Organic fertilizers are beneficial as they maintain and improve the structure of soil nutrients, however, if the microbial pathogen and pathogenic factors are present, they may lead to health problems and disease transmission. For this reason, evaluating the number of pathogens is necessary prior to using vermicompost in soil. Thus, this study aimed to evaluate the microbial quality of the produced vermicomposts and to compare them with existing Iranian standards to use the results for maintaining public health and also to ensure a step towards the use of vermicompost.

\section{Materials and methods}

This was a pilot-scale experimental study conducted in the laboratory of Yazd school of health to produce vermicompost from: (1) perishable organic waste, such as food waste and fruit and vegetable leftovers, (2) cow manure, (3) wastewater treatment plant sludge, the combination of cow manure with organic waste and municipal sewage sludge in equal proportions in two separate reactors with dimensions of $15 \times 30 \times 50 \mathrm{~cm}$.

The terms of operation on the pilot included a period of 8 weeks, aerobic conditions and an ambient temperature of $\left(30 \pm 5^{\circ} \mathrm{C}\right)$. Also moisture content range was $75-85 \%$ controlled by addition of water or aeration.

The Eisenia fetida worms were used to produce this vermicompost; a number of 1000 worms was available into each reactor. Determination of the microbial quality was carried out in early stages, during the process and on the final product. These tests included determining the most probable number (MPN) of FC bacteria and parasite eggs (Ascaris) of which the $\mathrm{A}_{1}$ Medium for $\mathrm{FC}$ and zinc sulfate were used for identifying parasite eggs, respectively (Association et al. 1915; Forbes et al. 2005).

After preparing the desired culture environments, $5 \mathrm{~g}$ of the sample was inoculated on a peptone water nonselective liquid enrichment broth and then was placed in an incubator shaker for $5 \mathrm{~min}$ at a temperature of $25^{\circ} \mathrm{C}$ and then in an incubator at $37^{\circ} \mathrm{C}$ for $16-20 \mathrm{~h}$. The nine-test tube fermentation method and $\mathrm{A}_{1}$ culture were used for identification of the fecal coliforms; the test was also carried out using the multiple test tube fermentation method with three dilutions including $1,0.1$ and 0.01 under bain-marie conditions and serology with $41.5{ }^{\circ} \mathrm{C}$ temperature for $20-24 \mathrm{~h}$.

For the test of parasite eggs detection, initially, half a test tube was filled with zinc sulfate solution. After transferring $1 \mathrm{~g}$ of the sample into the test tube, the suspension was prepared. The above suspension was passed through a two-layered filtrate and the filtered solution was returned to the test tube. Zinc sulfate solution was added to the test tube as long as a distance of $2-3 \mathrm{~mm}$ from the solution to the surface of the test tube opening was achieved. After centrifugation at a speed of $3000 \mathrm{rpm}$ for $1 \mathrm{~min}$, a loop from the zinc solution was obtained and added onto a slide containing a legal solution so that the identification process could be carried out under the microscope.

To evaluate the effects of treatment on the number of coliforms from the analysis test, one-way ANOVA and Duncan test were used, and a value of 0.05 was considered as sig. 


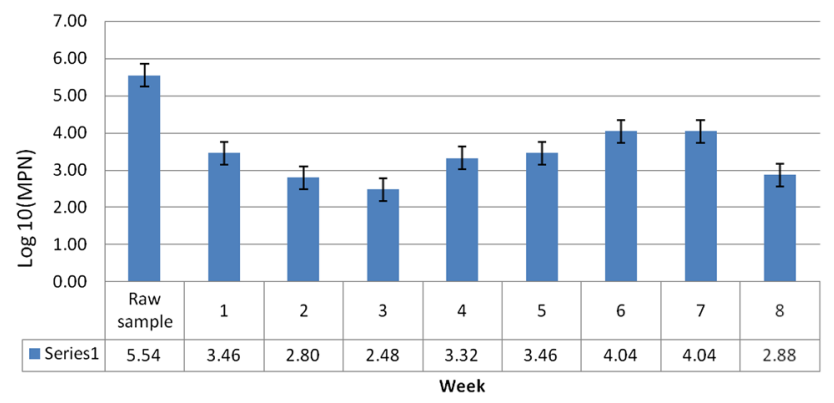

Fig. 1 The trend for the number of FC cow manure-organic waste during the 8 weeks $(\log 3$ is shown, the FC standard in class A compost of Iran)

\section{Results and discussion}

Given the results, there was a significant decrease in the number of $\mathrm{FC}$ in cow manure-organic waste so that the number of $\mathrm{FC}$ reached 800 from 350,000 MPN/g in the raw sample within 8 weeks (Fig. 1). In case of the raw samples, FC of cow manure-sludge was also significantly reduced pursuant to the data obtained. In this regard, the number of FC reached 2400 from 6,500,000 MPN/g within 8 weeks (Fig. 2).

In accordance with the Figs. 3 and 4, the mixture of cow manure-sludge and cow manure-organic waste had the highest parasite eggs $(22 / \mathrm{g})$ in the raw samples; this amount was completely removed in the second week via the vermicomposting process.

The physico-chemical properties of the raw samples are shown in Tables 1 and 2 including moisture, nitrogen, organic carbon (OC), $\mathrm{pH}$ and electrical conductivity (EC). The moisture content of organic waste had a noticeable difference to the cow manure and sewage sludge; however, other parameters showed no significant difference.

Removal of pathogens from such wastes as cow manure and sludge of wastewater treatment plant may be used for soil amendment which is very important in preventing the spread and transmission of disease. Vermicompost is able to remove significant amounts of pathogens. The passing of different treatments through the earthworm gut affects the microbial population in different treatments. Reduction of the number of pathogens in the vermicomposting process depends on different factors such as worm gut enzymes, coelomic fluid secretion (which has antibacterial properties) as well as the competition between different groups of microorganisms (Edwards et al. 2010; Hait and Tare 2011).

In the study of Monroy et al. (2008) on reduction of the density of nematodes, protozoa and FC by passing through earthworm intestine, results show a significant reduction of nematodes and FC and these results are consistent with those of present study. Reduction in the number of nematodes may be due to the fact that they are a part of the

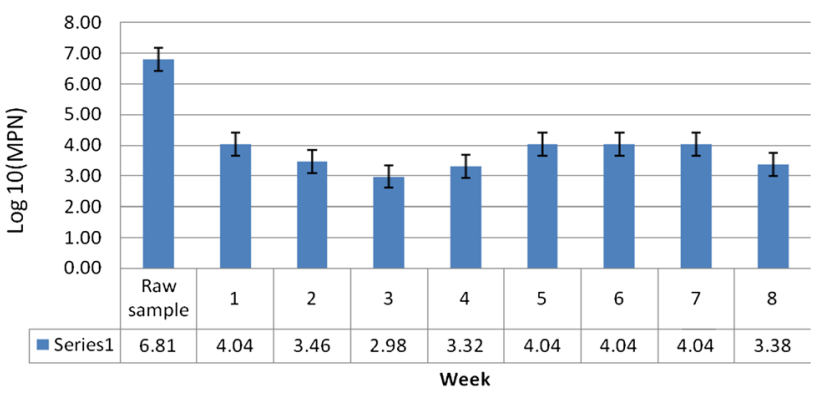

Fig. 2 The trend for the number of FC cow manure-sludge during the 8 weeks $(\log 3$ is shown, the FC standard in class A compost of Iran)

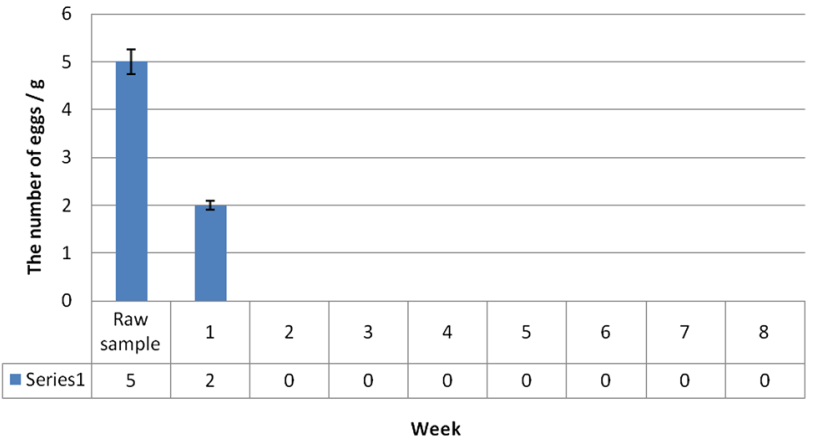

Fig. 3 The trend for the number of parasite eggs in vermicompost produced of a mixture of cow manure-organic waste within 8 weeks (number 1 in the figure shows the standard rate of parasite eggs in class A compost of Iran)

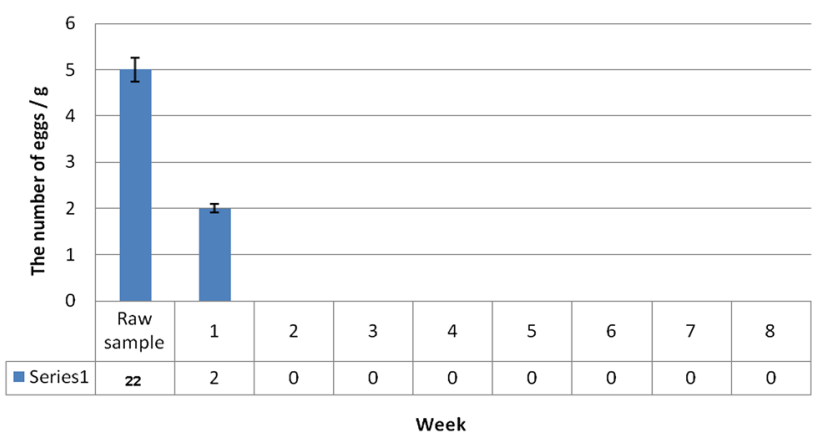

Fig. 4 The trend for the number of parasite eggs in vermicompost produced of a mixture of cow manure-sludge within 8 weeks (number 1 in the figure shows the standard rate of parasite eggs in class A compost of Iran)

earthworms' food; it may also be due to proteolytic enzyme activity to eliminate nematode and pathogens (Monroy et al. 2008). In this study, the highest coliforms removal in the cow manure-organic waste and cow manure-sludge, occurred in the week 3 ; however, the same result was seen in the week 2 by Monroy et al. (2009), showing the greatest reduction of coliforms in pig manure by passing through earthworm. This result is inconsistent with ours maybe due to differences in type of treatments or conditions of 
Table 1 Physico-chemical parameters of wastewater treatment plant sludge and cow manure in the raw samples

\begin{tabular}{|c|c|c|c|c|c|c|}
\hline \multirow[t]{2}{*}{ Parameters } & \multicolumn{3}{|c|}{ Cow manure } & \multicolumn{3}{|c|}{ Sludge } \\
\hline & Max & Minimum & Mean & Max & Minimum & Mean \\
\hline Moisture (\%) & 40 & 30 & $35.75 \pm 4.34$ & 20 & 15 & $17.25 \pm 2.21$ \\
\hline $\mathrm{EC}(\mathrm{mm}$ hose $/ \mathrm{cm})$ & 1.9 & 1.2 & $1.9 \pm 0.09$ & 2.9 & 1.3 & $2.17 \pm 0.69$ \\
\hline Organic carbon $(\%)$ & 75.13 & 50.21 & $64.4 \pm 11.42$ & 79.8 & 30.24 & $70.26 \pm 8.06$ \\
\hline$N(\%)$ & 2.26 & 1.91 & $2.11 \pm 0.15$ & 7.9 & 2.1 & $5.41 \pm 0.65$ \\
\hline $\mathrm{pH}$ & 7.5 & 6.2 & $7.1 \pm 0.75$ & 8.11 & 5.86 & $7.06 \pm 1.09$ \\
\hline
\end{tabular}

\begin{tabular}{llllll}
\hline & $N(\%)$ & Organic carbon $(\%)$ & EC $(\mathrm{mm} \mathrm{hose} / \mathrm{cm})$ & Moisture $(\%)$ & $\mathrm{pH}$ \\
\hline Minimum & 1.68 & 53.88 & 1.45 & 70 & 6.2 \\
Max & 1.7 & 54.16 & 1.46 & 73.7 & 6.4 \\
\hline
\end{tabular}

Table 2 Physico-chemical parameters of the raw domestic waste

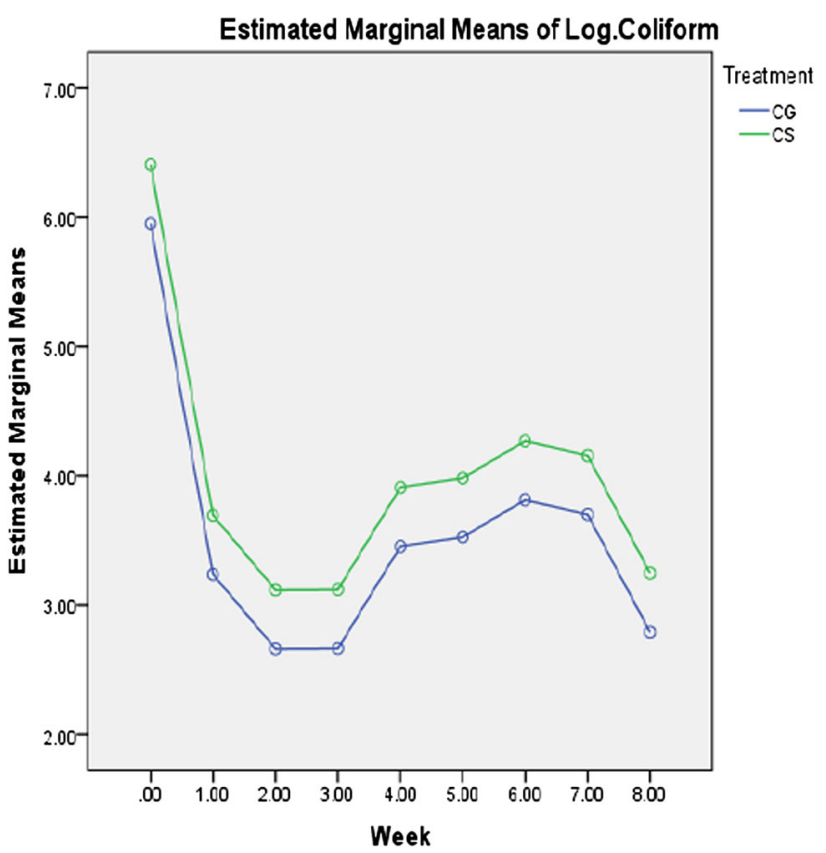

Fig. 5 Changing, the number of FC according to the week, and type of treatment. $C G$ cow manure-organic waste, $C S$ cow manurewastewater treatment sludge

detected and the number of FC significantly decreased after 60 days; this result is consistent with that of present work. In a study conducted by Edwards et al. (2010), results showed that the number of FC in the vermicompost process significantly reduced during 7 days; these results were parallel with those of present study. Furthermore, their results show significant decrease of parasitic worms after 3 days of vermicomposting (Edwards et al. 2010); these results are consistent with those of present study.

Eastman et al. (2001) indicated a significant reduction of FC after 7 days of vermicomposting, which is consistent with present study. In addition, the number of parasitic worms significantly reduced after 3 days which was also 
consistent with present study (Eastman et al. 2001). Finally, estimated marginal means of Log coliform was shown in Fig. 5 which presents changed number of FC according to the week and type of treatment.

\section{Conclusion}

The results of this study showed that vermicomposting can be used as a suitable method to transform perishable waste into fertilizer which is usable in agriculture. Earthworms have a great ability to reduce pathogens without the need of increased temperatures and the final product in terms of microbiological quality is placed as class A compost.

Acknowledgements The support President of the School of Public Health and laboratory experts which provide laboratory the possibility to carry out the research to be provided and their valuable guidance in this study helped us to appreciate.

\section{Compliance with ethical standards}

Conflict of interest We have no competing interests.

Open Access This article is distributed under the terms of the Creative Commons Attribution 4.0 International License (http://crea tivecommons.org/licenses/by/4.0/), which permits unrestricted use, distribution, and reproduction in any medium, provided you give appropriate credit to the original author(s) and the source, provide a link to the Creative Commons license, and indicate if changes were made.

\section{References}

Aira M, Gómez-Brandón M et al (2011) Selective reduction of the pathogenic load of cow manure in an industrial-scale continuous-feeding vermireactor. Bioresour Technol 102(20):9633-9637

Association APH, Association AWW et al (1915) Standard methods for the examination of water and wastewater. American Public Health Association, Washington, DC

Bowman DD, Liotta JL et al (2006) Ascaris suum Egg inactivation and destruction by the vermicomposting worm, Eisenia foetida. Proc Water Environ Fed 2006(2):11-18
Contreras-Ramos S, Escamilla-Silva E et al (2005) Vermicomposting of biosolids with cow manure and oat straw. Biol Fertil Soils 41(3):190-198

Domínguez, J. (2004). State-of-the-art and new perspectives on vermicomposting research. In: Earthworm ecology, O 8-193. 18 1 9. XI04. CRC Press LLC

Eastman BR, Kane PN et al (2001) The effectiveness of vermiculture in human pathogen reduction for USEPA biosolids stabilization. Compost Sci Util 9(1):38-49

Edwards CA, Arancon NQ et al (2010) Vermiculture technology: earthworms, organic wastes, and environmental management. CRC Press, Boca Raton

Forbes BA, Sahm D et al (2005) Diagnostic microbiology. Mosby, St. Louis

Hait S, Tare V (2011) Vermistabilization of primary sewage sludge. Bioresour Technol 102(3):2812-2820

Hill GB, Baldwin SA (2012) Vermicomposting toilets, an alternative to latrine style microbial composting toilets, prove far superior in mass reduction, pathogen destruction, compost quality, and operational cost. Waste Manag 32(10):1811-1820

Hill GB, Lalander C et al (2013) The effectiveness and safety of vermi-versus conventional composting of human feces with Ascaris suum ova as model helminthic parasites. J Sustain Dev 6(4):p1

Liu X, Sun Z et al (2009) Growth and stress responses of the earthworm Eisenia fetida to Escherichia coli O157: H7 in an artificial soil. Microb Pathog 46(5):266-272

Lui TA (1982) Earthworms, producers of biologically active substances. Zh Obshch Biol 24:149-154

Mohammadi A, Ebrahimi A et al (2012) Feasibility energy recovery potential of municipal solid waste in Northwest of Iran. Int J Environ Health Eng 1(1):14

Monroy F, Aira M et al (2008) Changes in density of nematodes, protozoa and total coliforms after transit through the gut of four epigeic earthworms (Oligochaeta). Appl Soil Ecol 39(2): 127-132

Monroy F, Aira M et al (2009) Reduction of total coliform numbers during vermicomposting is caused by short-term direct effects of earthworms on microorganisms and depends on the dose of application of pig slurry. Sci Total Environ 407(20):5411-5416

Rodríguez-Canché L, Vigueros LC et al (2010) Pathogen reduction in septic tank sludge through vermicomposting using Eisenia fetida. Bioresour Technol 101(10):3548-3553

Usepa E (1999) Control of pathogens and vector attraction in sewage sludge. Environmental Regulations and Technology, USEPA, Cincinnati 